\title{
Effect of the Affective Filter Hypothesis on CBI to Non-English-Majored College Students
}

\author{
You-gen Lou \\ School of Foreign Studies Yangtze University Hubei Province, China
}

\begin{abstract}
Content-based instruction (CBI) and Stephen Krashen's affective filter hypothesis play important roles in second language acquisition and foreign language teaching. This paper focuses on CBI and the affective factors which influence the English learning and English teaching of college students from China Three Gorges and Yangtze University based on CBI and affective filter hypothesis. Results showed that 1) emotional factors had a critical effect on the quality of Non-English-majored college students in CBI learning environment; 2) There were different impact of emotional filter on Non-English-majored college students such as personality, anxiety and attitude in CBI, which prevent them from improving learning English and majors; 3)It was differently affected by emotional factors to the good non-English-majored college learners and the bad non-English-majored college learners. They were both instrumental motivation, but the good non-English-majored college studentrs showed better than the bad non-English-majored college students at the anxiety, personality and attitude levels.
\end{abstract} Students

Index Terms - Affective Filter Hypothesis; CBI; College

\section{Introduction}

\section{A. Affective Filter Hypothesis}

The theoretical basis of the affective filter hypothesis is the affective filter theory. Due to the theory, success of second language acquisition depends on the learner's emotional factors. Krashen (1981) thought that learners' language input was filtered by emotion as the inner psychological factor learner, and the learners' received input was directly restricted by the number of filtering effect

The Affective Filter hypothesis states how affective factors relate to the second language acquisition process. The Affective Filter hypothesis captures the relationship between affective variables and the process of second language acquisition by positing that acquirers vary with respect to the strength or level of their Affective Filters. Those whose attitudes are not optimal for second language acquisition will not only tend to seek less input, but they will also have a high or strong Affective Filter--even if they understand the message, the input will not reach the part of the brain responsible for language acquisition, or the language acquisition device. Those with attitudes more conducive to second language acquisition will not only seek and obtain more input, they will also have a lower or weaker filter.

According to the affective filter hypothesis, certain emotions, such as anxiety, motivation and self-confidence interfere with the process of acquiring a second language. They function as a filter between the speaker and the listener that reduces the amount of language input the listener is able to understand. Learners with high motivation and selfconfidence and with low anxiety have low filters and so obtain and let in plenty of input. Learners with low motivation, little self-confidence and high anxiety have high filters and so receive little input and allow even less in.

\section{B. $C B I$}

Content-Based Instruction (CBI) has been defined as "the teaching of content or information in the language being learned with little or no direct or explicit effort to teach the language itself separately from the content being taught" (Krahnke, as cited in Richards \& Rodgers, 2001, p. 204). This teaching approach is considered by many researchers an effective and realistic teaching method in terms of combining language and content learning. According to Crandall (1999), $\mathrm{CBI}$ can be used in various ways depending on the skills being taught and includes not only traditional teaching methods such as grammar-based instruction or vocabulary development but also contemporary approaches such as communicative language teaching and humanistic methods (p. 604). CBI is related to Krashen's "Monitor Model". Krashen(1982) emphasized ways of decreasing learner anxiety, such as providing interesting texts as well as meaningful activities, which are comprehensible to learners, and CBI has the following essential features: "learning a language through academic content, engaging in activities, developing proficiency in academic discourse, fostering the development of effective learning strategies" (Crandall, p. 604). ContentBased Instruction is based on three main theories of language and four teaching models. Three main theories of language are: "language is text and discourse-based," "language use draws on integrated skills," and "language is purposeful"(Crandall, p. 208). Four teaching models are "theme-based approach", "sheltered-content courses", "adjunct courses"," language for special purposes".

\section{Research purpose}

The purpose of this study is to investigate the questions:

1) Is there impact of emotional factors on non-Englishmajored college students in CBI?

2) What are the major emotional factors on non-Englishmajored college students in CBI?

3) Is it same affected by emotional factor to the good non-English-majored college learners and the bad nonEnglish-majored college learners?

\section{Research design}

A. Subjects

In September 2013, 105 first-year non-English-majors were from China Three Gorges and Yangtze University responded to the affective factors on English learning 
Questionnaire. Among the 105 subjects, 59 were females and 46 males, average age 18 with Chinese as the main language. Their majors are chemistry, agriculture, history, plant protection, finance, biological technology.

\section{B. Research methods}

Research methods in this study include two parts: questionnaire and interview.

\section{1) Questionnaire}

The Affective Filter Questionnaire, written in Chinese, consists of two parts: One is concerned with personal profiles that is: name, age, and sex, major. The other part consists of 10 statements concerning emotional factors in English learning, which are divided into four major parts: motivation, confidence, anxiety and attitude The students indicate their opinions in terms of a five-point scale from 'this statement is never or almost never true of me' (1) to 'this statement is completely or almost completely true of me '(5). The questionnaire is designed by the author. Questionnaires were distributed to students and completed in class. Students were required to complete the questionnaire in 10 minutes. Then all 105 questionnaire were collected, and all collected 105 questionnaires were valid.

\section{2) Interview}

Teachers asked students about their ideas and emotions about English learning in CBI after questionnaires collected.

\section{Results and Analyses}

Table1 Affective Factors on Non-English-majored College students in CBI

\begin{tabular}{|c|c|c|c|}
\hline \multicolumn{2}{|r|}{ Affective Factors } & M & S.D. \\
\hline \multirow{5}{*}{ Motivation } & Learning English and major skills & 3.50 & 0.58 \\
\hline & Hunting for good jobs & 3.79 & 0.53 \\
\hline & Interested in English \&majors & 2.60 & 0.38 \\
\hline & Oversea study & 3.03 & 0.61 \\
\hline & Developing comprehensive quality & 2.91 & 0.50 \\
\hline \multirow{2}{*}{ Anxiety } & Fear of English in CBI & 3.47 & 0.51 \\
\hline & Fear of learning majors via English & 3.58 & 0.62 \\
\hline \multirow{2}{*}{ Personality } & Confidence on learning English \&majors & 2.84 & 0.44 \\
\hline & Sense of inferiority & 2.98 & 0.49 \\
\hline \multirow{2}{*}{ Attitude } & Patience & 3.01 & 0.19 \\
\hline & Learning English out of English class & 2.86 & 0.45 \\
\hline
\end{tabular}

\section{A. Affective Factors on Non-English-majored Colleges in CBI}

\section{1) Motivation}

Motivation is the psychological feature that arouses an organism to action towards a desired goal. In sociolinguistics, the most extensive research into the role of attitudes and motivation in SLA has-been conducted by Gardner and Lambert. Where "motivation" is concerned, they draw a basic distinction between an integrative and instrumental orientation to L2 learning. The former occurs when the learner wishes to identify with the culture of the L2 group. The later occurs when the learner's goals for learning the L2 are functional. As shown in Table 1, we can see that non-English-majored students' learning directed at passing an examination $(\mathrm{M}=3.50$, S.D.=0.58), Hunting for good jobs $(\mathrm{M}=3.79$, S.D.=0.53), or facilitating study of other subjects through the medium of the L2 are all examples of instrumentally motivated learning (Ellis Rod, 1999).However, students' motivation to interest of English $(\mathrm{M}=2.60$, S.D.=0.38), oversea study(M=3.03, S.D.=0.61) and development of comprehensive quality $(M=2.91$, S.D. $=0.50)$ were low. Most of non-English-majored college students' motivation belong to the instrumental motivation, which may be close to the intense job competition.

\section{2) Anxiety}

Anxiety is quiet possible the affective factor that most pervasively obstructs students' output in English learning. It is associated with negative feelings such as uneasiness, frustration, self-doubt, apprehension and tension (Harmer Jeremy, 2000). As analyzed before, non-English-majored college students in common university don't have a strong English foundation. The majority of them were anxious in class $(M=3.47$ S.D. $=0.51)$ and anxious on English examinations $(M=3.58$, S.D. $=0.62)$. Every time when English teachers invited the students as volunteers to answer questions in class, but the whole class would be completely quiet. Every student pretended to read their textbooks with their heads bending low. In such kind of embarrassing moment, the students may feel that the atmosphere is unsafe. Every student was fear of being chosen by English teachers to answer the question, because they were anxious of losing face before their classmates if they cannot have a good performance for answering the question.

\section{3) Personality}

Personality factors are interrelated with motivational factors. Briefly, it is hypothesized that the self-confident or secure person will be more able to encourage intake and will also have a lower filter. Traits relating to self-confidence (lack of anxiety, outgoing personality, and self-esteem) are thus predicted to relate to second language acquisition (Arnold Jane, 1998). Most of the students in west campus of Yangtze University come from the countryside, and more students in China Three Gorges come from workers' families or countryside. They thought their English foundation were not good since they begin learning English. They didn't have enough confidence on English learning ( $M=2.84$, S.D. $=0.44$ ), and they have strong sense of inferiority $(M=2.98$, S.D. $=0.49$ ). It may be that as non-English-majored college students they had to spend much of their time in their experiment or other assignments, so they hadn't have enough time to learn English, no confidence on English learning, and some of them feel inferior duo to their English ability.

\section{4) Attitude}

Attitude is very important to English learning. Patience $(\mathrm{M}=3.01$, S.D. $=0.19)$ from non-English-majored students is good for English learning. But, nowadays, everyone is busy and learning English out of English class ( $M=2.86$, S.D. $=0.45$ ). Students are busy with campus activities, dating, earning money or making friends. And some of them often go 
out with their supervisor to attend all kinds of academic meetings. These activities are good to enrich their college life but if they are too busy to have time in learning English that is abnormal. They need to reconsider their time management among activities, academic meetings and experiments because English learning is a time and energy consuming task. Rome is not built in one day. Although they are non-English-majored college students, they also need enough time to improve their English ability.

\section{B. Affective Factors on Good Non-English-majored College Learners and Bad Non-English-majored College Learners in $C B I$}

The good non-English-majored college learners and bad non-English-majored college learners, according to their marks from entrance to college examination, are, respectively, made up of $20 \%$ of all non-English-majored college learners.

As showed in Table 2and Table 3, we can see that both good non-English-majored college learners and bad nonEnglish-majored college learners were instrumental motivation, but the good non-English-majored college learners were Interested in English \&majors ( $M=3.71$, S.D. $=0.37)$, Oversea study $(M=3.53$, S.D. $=0.54)$. It may be that the good non-English-majored college learners hoped that they could learn English and majors better to oversea study. At the anxiety level, the bad non-English-majored college learners were anxious in CBI. It might be that their English or majors were not good, so they were difficult to learn English with this method. And the good non-English-majored college learners showed better than the bad non-English-majored college learners at the personality and attitude levels. It was likely that the good non-English-majored college learners had patience, more time to learn English and their majors to show confident and less sense of inferiority in CBI.

Table2 Affective Factors on Good Non-English-majored College Learners in CBI

\begin{tabular}{|c|c|c|c|}
\hline \multicolumn{2}{|c|}{ Affective Factors } & M & S.D. \\
\hline \multirow{4}{*}{ Motivation } & Learning English and major skills & 3.61 & 0.47 \\
\cline { 2 - 4 } & Hunting for good jobs & 3.19 & 0.43 \\
\cline { 2 - 4 } & Interested in English \&majors & 3.71 & 0.37 \\
\cline { 2 - 4 } & Oversea study & 3.53 & 0.54 \\
\cline { 2 - 4 } & Developing comprehensive quality & 3.46 & 0.52 \\
\hline \multirow{3}{*}{ Anxiety } & Fear of English CBI & 2.27 & 0.31 \\
\cline { 2 - 4 } & Fear of learning major via English & 2.28 & 0.42 \\
\hline \multirow{3}{*}{ Attitude } & Confidence on learning English \&majors & 3.32 & 0.45 \\
\cline { 2 - 4 } & Sense of inferiority & 2.18 & 0.48 \\
\cline { 2 - 4 } & Learning English out of English class & 3.48 & 0.19 \\
\cline { 2 - 4 } & Patience & 3.45 \\
\hline
\end{tabular}

Table3 Affective Factors on Bad Non-English-majored Colleges in CBI

\begin{tabular}{|c|c|c|c|}
\hline \multicolumn{2}{|c|}{ Affective Factors } & M & S \\
\hline \multirow{4}{*}{ Motivation } & Learning English and major skills & 2.37 & 0.57 \\
\cline { 2 - 4 } & Hunting for good jobs & 3.39 & 0.63 \\
\cline { 2 - 4 } & Interested in English \&majors & 2.12 & 0.37 \\
\cline { 2 - 4 } & Oversea study & 2.14 & 0.51 \\
\cline { 2 - 4 } & Developing comprehensive quality & 2.38 & 0.53 \\
\hline \multirow{3}{*}{ Anxiety } & Fear of English CBI & 3.27 & 0.31 \\
\cline { 2 - 4 } & Fear of learning major via English & 3.28 & 0.42 \\
\hline \multirow{3}{*}{ Attitude } & Confidence on learning English \&majors & 2.94 & 0.44 \\
\cline { 2 - 4 } & Sense of inferiority & 3.18 & 0.48 \\
\cline { 2 - 4 } & Learning English out of English class & 2.38 & 0.45 \\
\cline { 2 - 4 } & & 2.10 & 0.19 \\
\hline
\end{tabular}

\section{Conclusion}

This study is designed to explore theeffect of the affective filter on non-English-majored college students in CBI. 85 first-year non-English-majored college students from 3 classes in Yangtze University in Jingzhou city are chosen to respond to the questionnaire. The results showed that 1) emotional factors have a critical effect on the quality of NonEnglish-majored college students in CBI; 2) there are different impact of emotional filter on Non-English-majored college students such as personality, anxiety and attitude in CBI, which prevent them from improving learning English and majors; 3) It was differently affected by emotional factor to the good non-English-majored college learners and the bad non-English-majored college learners. They were both instrumental motivation, but the good non-English-majored college learners showed better than the bad non-Englishmajored college learners at the anxiety, personality and attitude levels. University and teachers should not ignore students' emotional education, and should pay attention to their affective factors and reduce their affective filter in order to improve students' learning English and majors. And before CBI, students should spend more time to learn English and major; English teachers should learn other major content from other major teachers to improve English teachers' other major skills and ability in CBI.

\section{References}

[1] Arnold Jane. Affect in Language Learning. Cambridge: Cambridge university press, 1998.

[2] Crandall, J. Content-based instruction

[3] (CBI). Concise encyclopedia of educational linguistics. Oxford, UK: Cambridge University Press 1999.

[4] Krashen, S. Second Language Acquisition and Second Language Learning. Oxford: Pergamon1981.

[5] Maslow, A. H. 1970. Motivation and Personality. New York : Haler Row.

[6] Platt.C.W.1988.Effects of causal attributions for Success on first-term college performance: A covariance structure model. Journal of Educational Psychology80: 569-578.

[7] Richards, J., \& Rodgers, T. Approaches and methods in language teaching. New York: Cambridge University Press 2001. 